\title{
PENERAPAN GOOD COPORATE GOVERNACE DALAM PENGELOLAAN KEUANGAN DESA DAN ASET DESA PADA BADAN USAHA MILIK DESA
}

\section{Asep Bambang Hermanto}

Program Magister Ilmu Hukum Universitas Pancasila abambang0706@gmail.com

\section{Daryan Ciptadi}

Alumni Magister Ilmu Hukum Universitas Pancasila 2018

\begin{abstract}
Abstrak
BUM Desa diatur dalam Pasal 87 sampai dengan Pasal 90 Undangundang No. 6 Tahun 2014 tentang Desa. Perihal desa dapat memiliki BUM Desa diatur dalam Pasal 87 Undang-Undang Nomor6 Tahun2014, yang menyatakan: "Desa dapat mendirikan Badan Usaha Milik Desa yang disebut BUM Desa", dan ayat (2)yang menyatakan:"BUM Desa dikelola dengan semangat kekeluargaan dan kegortongroyongan," dan ayat (3) yang mengatakan:"BUM Desa dapat menjalankan usaha di bidang ekonomi dan atau pelayanan umum sesuai dengan ketentuan peraturan perundang-undangan. Dari ketentuan di atas, artinya BUM Desa mempunyai potensi sebagai usaha mandiri masyarakat desa dalam memberikan kesejahteraan desa, untuk itu pentingnya peran kepala desa telah diberi kewenangan untuk menggali potensi desa ataukah mengadakan unit unit usaha bisnis untuk kepentingan masyarakat desa melalui pemasukan pada kas daerah, oleh karenanya peran kepala desa sangat penting. Agar dapat BUM Desa dikelola dengan baik dan profesional, maka kepala desa dan pengurus BUM Desa harus paham betul prinsip Good Corporate Governance dalam tata kelola BUM Desa.
\end{abstract}

Kata Kunci: BUM Desa, Kepala Desa, Good Corporate Governance

\section{Abstract}

Village -owned enterprice (Badan Usaha Milik Desa-BUM Desa) is stipulated under Article 87 to Article 90 Law No. 6 of 2014 on Village. In regards to village that is alloowed to own a BUM desa, the provision 
is regulated under Article 87 of Law No. 6 of 2014 on Village, which state that:"Village is allowed to establish a Villa-Owned Enterprise that is called BUM Desa", and paragraph (2) which states that : BUM Desa is managed with the familial and collective spirit", and paragraph (3) which state that :"BUM Desa may oparate activities in the economy sector/or public service according to the prevailling laws and regulations. From the abovementioned provision, it means that BUM Desa has the potential as an independent business entity for the village community to create prosperity for the village, therefore it is important for the Head of Village to uncover the village's potential by managing business units through BUM Desa as a revenuw for the village that will be used for the village community development. In order to realize this development, the head of village as an advisor to BUM Desa is obliged to understand and comprehent business management og BUM Desa by referring to Good Coporate Govermenace.

Keywords: BUM Desa, Head of Vallage, and Good Coporate Governace

\section{A. LATAR BELAKANG}

Dalam rangka mewujudkan tujuan negara sebagaimana tercantum pada Alinea Keempat Pembukaan UUD 1945 yaitu salah satunya adalah "memajukan kesejahteraan umum", ada yang berpendapat bahwa Indonesia menganut paham negara kesejahteraan (welfare state). Negara Indonesia memang sejak didirikan bertekad menetapkan dirinya sebagai negara yang berdasar atas hukum, sebagai negara hukum (rechtsstaat). Bahkan rechtsstaat Indonesia itu ialah rechtsstaat yang memajukan kesejahteraan umum, mencerdaskan kehidupan bangsa, dan mewujudkan suatu keadilan sosial bagi seluruh rakyat Indonesia.

Guna mewujudkan kesejahteraan rakyat, pemerintah diberi kekuasaan yang tertuang dalam UUD 1945, yaitu negara menguasai kekayaan dan segala hal yang bermanfaat bagi kemakmuran dan kesejahteraan rakyat. Amanah dari Alinea Keempat Pembukaan Undang-Undang Dasar Tahun 1945 (UUD 1945), menyatakan:

“... untuk membentuk suatu Pemerintah Negara Indonesia yang melindungi segenap bangsa Indonesia dan seluruh tumpah darah Indonesia dan untuk memajukan kesejahteraan umum, mencerdaskan kehidupan bangsa, dan ikut melaksanakan ketertiban dunia yang berdasarkan kemerdekaaan, perdamaian abadi dan keadilan sosial..." 
Tindak lanjut, keinginan untuk mewujudkan tujuan negara tersebut, kemudian dituangkan ke dalam aturan dalam pasal-pasal UUD 1945. Salah satu pasalnya mengenai sistem perekonomian Indonesia tercatum dalam Pasal 33 UUD 1945, menyatakan:

(1) Perekonomian disusun sebagai usaha bersama berdasarkan atas asas kekeluargaan.

(2) Cabang-cabang produksi yang penting bagi negara dan yang menguasai hajat hidup orang banyak dikuasai oleh negara.

(3) Bumi dan air dan kekayaan alam yang terkandung di dalamnya dikuasai oleh negara dan dipergunakan untuk sebesar-besarnya kemakmuran rakyat.

(4) Perekonomian nasional diselenggarakan berdasarkan atas demokrasi ekonomi dengan prinsip kebersamaan, efisiensi berkeadilan, berkelanjutan, berwawasan lingkungan, kemandirian, serta dengan menjaga kesimbangan kemajuan dan kesatuan ekonomi.

(5) Ketentuan lebih lanjut mengenai pelaksanaan pasal ini diatur dalam undang-undang.

Terkait dengan sistem perekonomian Indonesia di atas, maka pemerintahan tugas utamanya adalah melaksanakan pembangunan nasional guna mewujudkan keadilan sosial badi seluruh rakyat Indonesia dengan segala ukuran keberhasilannya, tentu mampunyai dampak positif bagi kehidupan masyarakat, tetapi juga ketidakberhasilan mempunyai dampak negatifnya hal ini tidak terlepas dari pelayanan dari aparat pemerintah itu sendiri.

Saat ini, di era Presiden Joko Widodo, upaya yang dilakukan pemerintah dengan Nawa Cita-nya yaitu pada butir ketiga dari sembilan butir yang ada. Butir ketiganya adalah membangun Indonesia dari pinggiran dengan memperkuat daerah-daerah dan desa dalam kerangka negara kesatuan. Presiden yakin, pembangunan yang merata akan mempersatukan Indonesia dan pembangunan yang berkeadilan akan membuat Indonesia semakin kuat dalam menghadapi persaingan global. Hal ini dikemukakan Presiden Jokowi dalam pidato pada Sidang Tahunan MPR RI tanggal 16 Agustus 2017: ${ }^{1}$

"Kita ingin rakyat-rakyat Indonesia yang berada di pinggiran, di kawasan perbatasan, di pulau-pulau terdepan, di kawasan terisolir,

1 Norvan Akbar, "Realisasi Nawa Cita Butir Ketiga, Meningkatkan Kesejahteraan dari Pinggiran", diakses dari https://jpp.go.id/nasional/pembangunan-desa/309682-realisasi-nawa-cita-butirketiga-meningkatkan-kesejahteraan-dari-pinggiran, pada tanggal 17 Desember 2017. 
merasakan hadirnya negara, merasakan buah pembangunan, dan merasa bangga menjadi Warga Negara Kesatuan Republik Indonesia,"

Pembangunan ekonomi nasional pada saat ini lebih ditekankan pada pembangunan daerah atau membangun Indonesia dari pinggiran dengan memperkuat daerah-daerah dan desa. Landasan kontitusional mengenai pemerintahan daerah diatur dalam UUD 1945, Bab VI mengenai Pemerintahan Daerah yaitu mulai Pasal 18 jo. Pasal 18A, dan Pasal 18 B, yang intinya, bahwa adanya pemerintahan daerah baik ditingkat provinsi, kabupaten/ kota sampai dengan tingkat desa. Khusus keberadaan pemerintah daerah yang terkecil dari pemerintahan adalah desa. Desa merupakan suatu entitas penyelenggara urusan pemerintahan terkecil dalam sistem penyelenggaraan pemerintahan Negara Kesatuan Republik Indonesia (NKRI).

Bagi Indonesia, penyelenggaraan pemerintahan desa yang berkualitas berpotensi mendorong kesejahteraan masyarakat desa, sekaligus meningkatkan kualitas hidup di desa. Sebagai strata pemerintahan terkecil, desa memainkan peranan sentral dalam agenda pembangunan nasional di mana sebagian masyarakat Indonesia hidup di pedesaan. ${ }^{2}$ Dalam pelaksanaan pemerintahan desa, kepala desa berwenang memimpin penyelenggaraan pemerintahan desa dan memegang kekuasaan, yaitu salah satunya adalah dalam hal tata kelola keuangan dan aset desa, hal ini diatur dalam Undangundang No. 6 Tahun 2014 tentang Desa.

Salah satu usaha desa untuk mengembangkan desanya maupun masyarakat desanya, kepala desa mempunyai peranan aktif dalam pengembangan kehidupan masyarakat desa. Oleh karenanya, salah satu kewenangan kepala desa adalah mendirikan Badan Usaha Milik Desa (BUM Desa). BUM Desa merupakan unit usaha desa yang dikelola atau diurus oleh kepala desa demi mewujudkan kemakmuran desa dengan mengelolaan unit unit usaha. Seiring dengan program Nawa Cita di atas, mengenai pengelolaan BUM Desa sebagaimana diatur dalam Pasal 87 sampai dengan Pasal 90 Undang-undang No. 6 Tahun 2014 tentang Desa.

Pasal 87 Undang-Undang Nomor 6 Tahun 2014, menyatakan: "Desa dapat mendirikan Badan Usaha Milik Desa yang disebut BUM Desa", dan ayat (2) nya:"BumDes dikelola dengan semangat kekeluargaan dan

2 M. Irwan Tahir, Sejarah Perkembangan Desa di Indonesia: Desa di Masa Lalu, Masa Kini dan Bagaimana Masa Depannya, (Jurnal Ilmu Pemerintahan-Pencerahan Untuk Memajukan Pemerintahan Edisi 38 Tahun 2012, Jakarta: Masyarakat Ilmu Pemerintahan, 2012), hlm. 17. 
kegortongroyongan." Pada ayat (3) nya:"BUM Desa dapat menjalankan usaha di bidang ekonomi dan atau pelayanan umum sesuai dengan ketentuan peraturan perundang-undangan."

Ketentuan dalam pasal-pasal di atas mempunyai arti bahwa BUM Desa mempunyai potensi sebagai usaha mandiri masyarakat desa dalam memberikan kesejahteraan desa, untuk itu pentingnya peran kepala desa telah diberi kewenangan untuk mengelola dan menggali potensi desa ataukah mengadakan bisnis bisnis berskala desa, misalnya usaha-usaha asli desa terus dikembangkan, koperasi desa selain usaha simpan pinjam, juga diarahkan untuk mengembangkan usaha-usaha dagang terkait kebutuhan sandang pangan ataupun mengembangkan bisnis lokal. Agar bisnis-bisnis di desa dapat berkembang dengan baik, maka pengelolaan dari BUM Desa itu sendiri harus berjalan secara profesional.

Hasil usaha BUN Desa dimanfaatkan untuk mengembangkan usaha dan mengembangkan desa, pemberdayaan masyarakat desa, dan pemberian bantuan untuk masyarakat miskin melalui hibah, bantuan sosial, dan kegiatan dana bergulir yang ditetapkan dalam anggaran pendapatan dan belanja desa. Hal ini sesuai aturan dalam Pasal 89 Undang-undang No. 6 Tahun 2014 tersebut.

Hal tersebut di atas jelas bahwa organ BUM Desa dapat menjalankan bisnis sosial (social business) sederhana yang memberikan pelayanan umum (serving) kepada masyarakat dengan memperoleh keuntungan finansial, menjalankan bisnis penyewaan (renting) barang untuk melayani kebutuhan masyarakat desa dan ditujukan untuk memperoleh Pendapatan Asli Desa (PAD), menjalankan usaha perantara (brokering) yang memberikan jasa pelayanan kepada warga, menjalankan bisnis yang berproduksi dan/atau berdagang (trading) barang-barang tertentu untuk memenuhi kebutuhan masyarakat maupun dipasarkan pada skala pasar yang lebih luas, menjalankan bisnis keuangan (financial business) yang memenuhi kebutuhan usaha-usaha skala mikro yang dijalankan oleh pelaku usaha ekonomi desa, dan menjalankan usaha bersama (holding) sebagai induk dari unit-unit usaha yang dikembangkan masyarakat desa baik dalam skala lokal desa maupun kawasan perdesaan. ${ }^{3}$

Dalam menjalankan unit unit usaha desa melalui BUM Desa, hal peting yang menjadi perhatian bagi kepala desa adalah pengelola usaha terkait

3 Indonesia (3), Peraturan Menteri Desa, Pembangunan Daerah Tertinggal, dan Transmigrasi Tentang Pendirian, Pengurusan dan Pengelolaan, dan Pembubaran Badan Usaha Milik Desa, Permendes PDTT No. 4 Tahun 2015, BN Nomor 296 Tahun 2015, Bagian Keempat Klasifikasi Jenis Usaha BUMDesa. 
dengan pengelolaan keuangan desa itu sendiri. Pengelolaan keuangan desa diatur dalam Pasal 3 Permendagri No. 113 Tahun 2014 tentang Pengelolaan Keuangan Desa (selanjutnya disebut Permendagri 113/2014), kepala desa adalah pemegang kekuasaan pengelolaan keuangan desa dan mewakili pemerintah desa dalam kepemilikan kekayaan milik desa yang dipisahkan. 4 Kepala desa sebagai pemegang kekuasaan pengelolaan keuangan desa mempunyai kewenangan:

a. menetapkan kebijakan tentang pelaksanaan APBDesa;

b. menetapkan Pelaksana Teknis Pengelolaan Keuangan Desa (PTPKD);

c. menetapkan petugas yang melakukan pemungutan penerimaan desa;

d. menyetujui pengeluaran atas kegiatan yang ditetapkan dalam APBDesa; dan

e. melakukan tindakan yang mengakibatkan pengeluaran atas beban APBDesa.

Ketentuan lain juga diatur, bahwa dalam hal pengelolaan BUM Desa, berdasarkan Permendes PDTT 4/2015 bahwa organisasi pengelola BUM Desa terpisah dari organisasi pemerintahan desa. Susunan kepengurusan organisasi pengelola BUM Desa terdiri dari Penasihat, Pelaksana Operasional dan Pengawas. Dalam Pasal 11 Permendes PDTT 4/2015 disebutkan bahwa penasihat BUM Desa dijabat secara ex officio oleh kepala desa, yang bersangkutan yang berkewajiban memberikan nasihat kepada Pelaksana Operasional dalam melaksanakan pengelolaan BUM Desa, memberikan saran dan pendapat mengenai masalah yang dianggap penting bagi pengelolaan BUM Desa dan mengendalikan pelaksanaan kegiatan pengelolaan BUM Desa. Kepala desa sebagai penasihat BUM Desa pun berwenang meminta penjelasan dari Pelaksana Operasional mengenai persoalan yang menyangkut pengelolaan usaha desa, dan melindungi usaha desa terhadap hal-hal yang dapat menurunkan kinerja BUM Desa. Selain itu, kepala desa mempunyai kewenangan untuk pengelolaan aset desa, dan kepala desa yang bertanggungjawab atas pengelolaan aset desa tersebut. ${ }^{5}$

Begitu besar peran dan strategisnya kepala desa dalam mengelola BUM Desa membuat kepala desa memiliki tanggung jawab hukum yang luas, terlebih dalam pengelolaan keuangan desa dan aset desa pada BUM Desa. Persoalan yang sering terjadi dalam pengelolan keuangan dan aset desa

4 Indonesia (4), Peraturan Menteri Dalam Negeri Tentang Pengelolaan Keuangan Desa, Permendagri No. 113 Tahun 2014, BN Nomor 2093 Tahun 2014, Ps 3 ayat 1.

5 Indonesia (5), Peraturan Menteri Dalam Negeri Tentang Pengelolaan Aset Desa, Permendagri Nomor 1 Tahun 2016, BN Nomor 53 Tahun 2016, Ps 4. 
pada BUM Desa, yaitu seringnya terjadi kekeliruan kepala desa dalam data administratif dalam pengelolaan keuangan dan aset desa. Data adminstratif yang seharusnya secara hukum merupakan tanggungjawab kepala desa dalam mengelola keuangan BUM dan aset desa, karena tanpa bukti pengeluaran dan pemasukan dalam pengelolaan keuangan dan data aset desa akan menimbulkan tidak tertib administrasi, dan mempunyai potensi akan menimbulkan kerugian negara. Hal inilah yang menjadi perhatian serius bagi kepala daerah dan para pelaksana BUM Desa, maka pengelolaan BUM Desa haruslah sesuai ketentuan hukum dan penerapan good corporate governance, agar tujuan pembangunan desa dapat tercapai sesuai amanah konstitusi dan peraturan perundang-undangan, khusus undang undang desa.

\section{B. PENGELOLAAN DANA DAN ASET DESA PADA BUM DESA OLEH PEMERINTAH DESA CQ KEPALA DESA}

Konsep desentralisasi adalah penyerahan sejumlah urusan pemerintahan dari pemerintah pusat kepada pemerintah daerah tingkat sehingga menjadi urusan rumah tangganya daerah itu sendiri, hal itu sesuai dengan Pasal 1 UU Desa, bahwa Pemerintahan Desa adalah penyelenggaraan urusan pemerintahan dan kepentingan masyarakat setempat dalam sistem pemerintahan Negara Kesatuan Republik Indonesia (NKRI). Artinya melalui undang-undang tersebut pemerintah pusat telah memberikan ruang kepada pemerintah desa untuk menyelenggarakan pemerintahan desa.

Dalam penyelenggaraan Pemerintah Desa, maka usulan prakarasa, wewenang dan tanggung jawab mengenai urusan-urusan yang diserahkan tadi sepenuhnya menjadi tanggung jawab desa itu, baik mengenai politik kebijaksanaan, perencanaan dan pelaksanaannya maupun mengenai segisegi pembiayaannya. Desentralisasi bertujuan agar pemerintah dapat lebih meningkatkan efisiensi serta efektivitas fungsi-fungsi pelayanannya kepada lapisan masyarakat. ${ }^{6}$ Guna melaksanakan pembangunan desa, salah satu solusinya dengan adanya pendirian BUM Desa oleh Pemerintah Desanya, dalam hal ini kepala desa. Oleh karenanya, Pemerintah Desa untuk melakukan pembangunan desa nya wajib mendayagunakan segala potensi ekonomi desa. Kondisi tersebut mendorong setiap Pemerintah Desa untuk memberikan "goodwill" dalam merespon pendirian BUM Desa.

6 Sakinah Nadir, Otonomi Daerah dan Desentralisasi Desa: Menuju Pemberdayaan Masyarakat Desa, (Universitas Hassanudin, Jurnal Politik Profetik, vol. 1 No. 1 Tahun 2013), hlm. 82. 
BUM Desa merupakan salah satu wadah ekonomi yang beroperasi di pedesaan. BUM Desa harus memiliki perbedaan dengan wadah ekonomi pada umumnya atau mempunyai kekhasannya desa, sebagaimana dalam penjelasan pada Pasal 87 UU Desa, bahwa BUM Desa spesifik tidak dapat disamakan dengan badan hukum seperti perseroan terbatas, CV, atau koperasi. Dengan demikian, tujuan berdirinya BUM Desa selain untuk menyelenggarakan pemerintahan desa dalam pembangunan dan membantu Pemerintah Desa untuk memenuhi kebutuhan masyarakat desa. BUM Desa juga dapat melaksanakan fungsi pelayanan jasa, perdagangan, dan pengembangan ekonomi dan lain-lainnya sesuai kondisi yang dimungkinkan untuk itu.

Dalam peningkatkan sumber pendapatan desa, BUM Desa dapat menghimpun dana melalui tabungan dalam skala lokal masyarakat desa, misalnya melalui pengelolaan dana bergulir dan simpan pinjam. BUM Desa dalam kegiatannya tidak hanya berorientasi pada keuntungan keuangan, tetapi juga berorientasi untuk mendukung peningkatan kesejahteraan masyarakat desa.

Peran BUM Desa juga diharapkan dapat mengembangkan unit usaha dalam mendayagunakan potensi ekonomi. Dalam hal kegiatan usaha dapat berjalan dan berkembang dengan baik, sangat dimungkinkan pada saatnya BUM Desa mengikuti atura sebagai badan hukum yang telah ditetapkan dalam ketentuan peraturan perundang-undangan, dan pengelola wajib bertindak secara profesional dengan misinya adalah memajukan desa dan dapat memberikan pelayanan kepada masyarakat desa dengan memenuhi kebutuhan mereka sehari-harinya melalui unit-unit usaha BUM Desa.

Dengan demikian, bahwa arah dari pendirian BUM Desa dapat berbentuk bukan badan hukum, akan tetapi nantinya dimungkinkan bahwa BUM Desa sebagai badan hukum. BUM Desa sebagai badan hukum dimaksudkan bahwa keberadaan dan kinerja BUM Desa mampu memberikan kontribusi yang signifikan terhadap peningkatan kesejahteraan warga desa, terlebih tindak/pengeloaan BUM Desa dapat dipertanggungjawabkan secara hukum seperti badan hukum perseroan. BUM Desa sebagai badan hukum tentunya ada kewajiban dan ada hak, serta tanggungjawannya sebagai pengurus dibatasi sesuai aturan hukum.

Berkaitan dengan pengelolaan yang dilakukan oleh kepala desa, tentunya hal-hal yang terkait dengan itu misalnya pengelolaan dana/keuangan dan aset desa. Oleh karena itu, kepala desa baik sebagai pemerintah desa wajib 
mengawasi dan mengotrol dalam mengelola keuangan desa dan aset desa demi pembangunan desa. Selain itu kepala desa berperanan selaku koordinator dalam kegiatan usaha yang dijalankan di desa. Peran kepala desa dalam pemerintahan adalah sebagai pelayan dan pengayom masyarakat. Untuk melakukan hal itu semua, maka kunci pokoknya bagaimana kepala desa dapat meningkatkan taraf kehidupan masyarakat secara ekonomi agar kebutuhan hidup masyarakat desa dapat terpenuhi. Maka peran dan fungsi pemerintahan desa yang dipegang kepala desa adalah mewujudkan kesejahteraan masyarakat.

Ukuran maju atau tidaknya suatu desa dapat di lihat dari peran kepala desa nya, pembangunan desa sangat ditentukan oleh kepala desa. Oleh karena itu, kepala desa punya kewajiban untuk membantu masyarakat dalam membangun desa dan masyarakat desa-nya. Membangun desa melalui membangun masyarakat sangat penting, agar kemandirian masyarakat dalam pembangunannya desa nya lebih mandiri dan maju dalam bidang perekonomian masyarakat sangat-lah penting. Jadi peran kepala desa dalam pembangunan ekonomi masyarakat khususnya, dalam hal ini tertuju pada masyarakat desa seperti melaksanakan kooordinasi, mengevaluasi, tentang segala hasil kegiatan dan usaha di desa, serta pertanggung jawabannya merupakan faktor yang utama dalam pembangunan perekonomian masyarakat desa.

Dalam hal pelayanan kepada masyarakat, kurangnya infrastruktur di daerah-daerah pedesaan seringkali dianggap sebagai penyebab mendasar terjadinya kemiskinan di pedesaan di Indonesia. Infrastruktur pedesaan yang tidak layak menyebabkan terhambatnya pertumbuhan ekonomi karena membatasi pertumbuhan produktivitas dan merintangi perkembangan kapital Indonesia. Pemahaman tentang peranan pembangunan infrastruktur di dalam pengentasan pedesaan mendorong pemerintah pusat untuk mengarahkan dana desa yang jumlah signifikan kepada pemerintah desa melalui kepala desa yang salah satunya agar dikelola melalui BUM Desa.

Pelaksanaan BUM Desa sangat tergantung dengan struktur organisasinya. Struktur organisasi selaku pengelola BUM Desa terdiri dari penasihat dan pelaksana operasional. Secar struktural bahwa jabatan penasihat secara ex-officio dijabat oleh kepala desa. Kepala desa ex officio mempunyai tugas untuk melakukan pengawasan dan memberikan nasihat kepada pelaksana operasional dalam menjalankan kegiatan pengurusan dan pengelolaan usaha desa, serta meminta penjelasan kepada pelaksana operasional 
mengenai pengurusan dan pengelolaan usaha desa. Pelaksana operasional merupakan perseorangan yang diangkat dan diberhentikan oleh kepala desa, dan mempunyai tugas untuk mengurus dan mengelola BUM Desa. Pengurusan dan pengelolaan BUM Desa tersebut dilakukan sesuai anggaran dasar dan anggaran rumah tangga.

Dalam pengelolaan BUM Desa, ada poin penting dan krusial dalam pengelolaan nya terkait dengan pembebanan kerugian jika BUM Desa tersebut dinyatakan pailit oleh Pengadilan Niaga. Jika merujuk pada Pasal 139 PP No. 43 Tahun 2014 tentang Peraturan Pelaksanaan Undang-Undang Nomor 6 Tahun 2014 tentang Desa yang berbunyi :

\section{"Kerugian yang dialami oleh BUM Desa menjadi tanggung jawab Pelaksana Operasional BUM Desa"}

Sebagaimana uraian ketentuan hukum di atas, maka tanggung jawab terhadap kerugian yang dialami oleh BUM Desa memang hanya ditanggung oleh pelaksana operasional. Tetapi jika melihat modal, sumber dana, keuntungan, dan pelaksanaan BUM Desa tidak serta merta dilakukan mutlak oleh menjadi tanggung jawab pelaksana operasional, akan tetapi menjadi tanggung jawab adalah kepala desa selaku penasihat BUM Desa, hal dikarenakan BUM Desa terbentuk dari Penyertaan Modal Desa dan Penyertaan Modal Masyarakat Desa yang merupakan tanggung jawabnya kepala desa sebagai pengelolanya, oleh karena itu, kepala desa dalam memberikan nasihat dan pengelolaan BUM Desa harus dibekali ilmu pengetahuan mengenai tata kelola badan usaha milik desa yaitu pemahami dan menerapkan prinsip good corporate goverment dengan landasan pijakannya adalah Tranparancy, Accountable, Responsip, Independen, dan Fairness. Dengan demikian, dalam mengelola badan usaha milik desa, kepala desa, aparatur desa, dan masyarakat desa yang dilibatkan dalam pengurusan usaha-usaha milik desa wajib memahami dan melaksanakan prinsip good coporate goverment tersebut. Karena dalam pengelolaan usaha usaha desa akan maju dan berkembang apabila para pengelola menjalan tugasnya dengan terbuka, bertanggungjawab, mau menerima masukan, tidak dapat dipengaruhi, dan jujur. Kelima prinsip ini yang harus dipegang oleh kepala desa dan para pelaksana lainnya, agar usaha-usaha unit unit desa dapat berkembang sesuai ketentuan hukum yang berlaku, karena majunya usaha desa melalui wadah BUM Desa akan memberikan dampak terhadap kemajuan dan kesejahteraan masyarakat desa. Hal inilah yang harus menjadi perhatian para kepala desa selaku penanggungjawab dalam penyelenggraan 
Asep Bambang Hermanto \& Daryan Ciptadi - PENERAPAN GOOD COPORATE GOVERNACE ...

pemeritahan desa sebagaimana amanat undang undang desa dan peraturan lainnya.

\section{PENERAPANGOODCOPORATE GOVERNACEDALAM PENGELOLAAN KEUANGAN DESA DAN ASET DESA OLEH BUM DESA}

BUM Desa baik yang berbentuk bukan badan hukum maupun badan hukum, jika di lihat dari struktur modal berasal dari kekayaan desa yang dipisahkan, maka tunduk pada ranah hukum publik (UU No. 6 Tahun 2014 tentang Desa dan UU No. 17 Tahun 2003 tentang Keuangan Negara). Tujuan utama dari kegiatan BUM Desa adalah melakukan bisnis dengan target keuntungan untuk kesejahteraan masyarakat desa. Dalam kegiatan bisnis BUM Desa pasti mengadung risiko dan tidak selalu menguntungkan bahkan dapat menimbulkan kerugian BUM Desa.

Dalam konteks penerapan government judgment rule dalam pengelolaan keuangan desa dan aset desa oleh BUM Desa, masalah timbul ketika keputusan bisnis yang diambil oleh pengelolan BUM Desa ternyata membawa kerugian bagi BUM Desa. Perbedaan perspektif dalam memandang terjadinya kerugian ini menjadi persoalan hukum konkrit yang dihadapi BUM Desa sebab pengelola BUM Desa dapat dipidana bila terjadi kerugian pada BUM Desa. Ancaman pidana ini dapat dilakukan sebab keuangan BUM Desa merupakan keuangan desa sehingga kerugian BUM Desa dapat menjadi kerugian negara yang dapat diancam dengan pidana korupsi.

Persoalan kerugian BUM Desa erat kaitannya dengan persoalan kerugian keuangan negara. Persoalan keuangan negara selalu terkait dengan dua hal yakni pengelolaan keuangan dan pertanggungjawabannya. Dua hal ini merupakan aspek pokok yang sudah diatur sejak berlakunya Indische Comptabiliteitswet 1925 (ICW 1925) yang merupakan landasan hukum pengaturan keuangan negara pada zaman Hindia Belanda.

Pemeriksaan pengelolaan dan tanggungjawab keuangan negara juga dilakukan dengan tujuan untuk memastikan kepatuhan terhadap peraturan perundang-undangan. Terkait pengawasan pengelolaan keuangan desa dan aset desa pada BUM Desa, pelaksanaannya terkait dengan paradigma pengelolaan BUM Desa yang berdasarkan pada business judgement rules. Keuangan BUM Desa merupakan keuangan negara, namun dalam paradigma pengawasan keuangan negara pada BUM Desa, menurut penulis jangan hanya berdasarkan pada paradigma business judgement rules tetapi 
juga berdasarkan pada paradigma pengawasan keuangan negara dalam penyelenggaraan pemerintahan (government judgement rules).

Penerapan government judgement rules dalam pengelolaan BUM Desa, harus sejalan dengan penerapan prinsip Good Corporate Governance (GCG). GCG adalah sebuah prinsip yang diterapkan di dalam sebuah organisasi, yang ditujukan untuk mengatur hubungan diantara orang-orang yang terlibat demi terbentuk kinerja yang baik, yang diharapkan dapat memberikan nilai tambah dari dari organisasi tersebut. Prinsip GCG memiliki asas-asas yang terkandung didalamnya, adapun asas-asas dari prinsip GCG adalah:

1. Transparansi (Transparency);

2. Akuntabilitas (Accountability);

3. Responsibilitas (Responsibility);

4. Independensi (Independency);

5. Kewajaran dan Kesetaraan (Fairness).

BUM Desa harus dapat mengemban fungsi guna pencapaian tujuan pendiriannya sekaligus harus bisa bersaing dengan swasta dalam lapangan privat. Dalam mewujudkan upaya ini, BUMN dihadapkan pada dua prinsip yang harus dipatuhi yakni prinsip pengelolaan keuangan negara yang berkonsekuensi pada situasi pemeriksaan dan tanggungjawab pengelolaan keuangan negara dan prinsip good corporate governance sebagai pedoman dalam menjalankan BUM Desa. Prinsip pengelolaan keuangan negara harus diemban oleh BUM Desa dalam kapasitanya sebagai perpanjangan tangan negara dan karena keuangan BUM Desa merupakan keuangan negara.

Berkaitan dengan pengaturan GCG dalam Pengelolaan BUM Desa, UU Desa maupun peraturan pelaksanaannya tidak mengatur bagaimana pelaksanaan prinsip Good Corporate Governance dalam pengelolaan BUM Desa. Sehingga dalam prakteknya pengelolaan BUM Desa di desa-desa sendiri menjadi tidak jelas dan berakibat pada tidak terwujudnya Good Corporate Governance dan berkontribusi kepada BUM Desa tidak berjalannya sesuai prinsip government judgment rules. Hal tersebut dapat diketahui dengan adanya kebebasan kepala desa dalam mengangkat pelaksana operasional BUM Desa yang berindikasi pemilihan berdasarkan hubungan kekerabatan tanpa mempertimbangkan kredibilitas individu, tidak jelas apakah BUM Desa dapat dengan bebas menjalankan usahanya sebagai pelaku ekonomi yang memiliki otonomi penuh hanya dengan menjalankan prinsip business judgement rules dengan orientasi kepada profit saja. Hal-hal inilah yang 
akan membawa dapak negatif terhadap pengelolaan BUM Desa itu sendiri, karena faktor ketidak profesionalan pengurusnya atau ketidaktahuan dalam pengelolaan usaha-usaha desa melalui BUM Desa ataukah faktor-faktor lainnya yang saling pengaruh mempengaruhinya.

\section{KESIMPULAN}

Peranan kepala desa memegang kewenangan cukup besar dalam pengelolaan keuangan desa dan aset desa guna mewujudkan pembangunan desa. Atas kewenangan tersebut, Kepala desa memiliki tanggung jawab hukum terhadap pengelolaan keuangan dan aset sangatlah besar. Oleh karenanya, Kepala desa sebagai penasehat dalam pengelolaan BUM Desa mempunyai peran penting untuk mengelolaannya melalui nasihat-nasihat kepada pengurus BUM Desa dengan memberikan: a) Saran kepada pelaksana operasional dalam melaksanakan pengelolaan BUM Desa, b) Saran dan pendapat mengenai masalah yang dianggap penting bagi pengelolaan BUM Desa, c) Dorongan dalam pelaksanaan kegiatan pengelolaan BUM Desa.

Kepengurusan BUM Desa yang selama ini dilakukan ternyata BUM Desa tidak berjalan sesuai aturan hukum dan prinsip good corporate governace, BUM Desa sebagai salah satu unit usaha desa yang diharapkan untuk keuntungan yang merupakan pemasukan kas desa tidak pernah memberikan keuntungan dengan baik, karena dalam praktiknya pengurus BUM Desa termasuk Kepala desa kurang memahami bagaimana menerapkan prinsipprinsip bisnis agar bisa terlaksana dengan benar. Oleh karena itu, penerapan good corporate governace haruslah menjadi suatu keharusan yang harus dijalankan oleh pengurus BUM Desa. Karena selama ini kepengurusan BUM Desa bersama Kepala Desa masih kesulitan untuk mengimplementasikan hal hal teknis dan opersional, pada akhirnya Kepala desa dan pengurus BUM Desa lainnya hanya dapat menafsirkan norma hukum (aturan) secara bebas, termasuk hal terkaiot dengan laporan pertanggungjawabannya, baik itu masalah keuangan maupun pendataan aset aset desa.

Agar pengelolaan BUM Desa dapat berjalan dengan benar dan menjadikan salah satu unit usaha bisnis desa yang profit, maka Kepala desa dan para pengurus BUM Desa harus memahami aturan hukum dan prinsip bisnis dengan menerapkan good coporate governace dengan pengelolaan BUM Desa mengacu pada : transparansi (transparency); akuntabilitas (accountability); responsibilitas (responsibility); independensi 
(independency); and kewajaran dan Kesetaraan (fairness) atau disingkat TARIF. Dengan demikian, berpegang pada tata kelola yang baik atau good corporate governace dengan TARIF nya, maka pengelolan BUM Desa akan berjalan dengan benar dan sesuai aturan, kemudian hasil akhirnya dapat memberikan keuntungan kepada BUM Desa yang merupakan bagian dari usaha milik desa demi kesejahteraan masyarakat desa.

\section{DAFTAR PUSTAKA}

\section{A. BUKU}

Asshiddiqie, Jimly. Pengantar Ilmu Hukum Tata Negara Jilid II. Jakarta: Sekertariat Jenderal dan Kepaniteraan Mahkamah Konstitusi RI, 2006.

. Konstitusi Ekonomi. Jakarta: Penerbit Buku Kompas, 2010.

Boen, Hendra Setiawan, Bianglala Business Judgment Rule. Jakarta: Tatanusa, 2008.

Chabib Soleh dan Heru Rachmansjah. Pengelolaan Keuangan Desa. Bandung: Fokusmedia, 2014.

Darmawan Tribowo dan Sugeng Bahagijo, Mimpi Negara Kesejahteraan. Jakarta: LP3ES Indonesia, 2006.

Juliantara, Dadang. Pembahuruan Desa, Bertumpu Pada Angka Terbawah,. Yogyakarta: Lappera Pustaka Utama, 2003.

Kartohadikoesoemo, Soetardjo. Desa. Bandung: Sumur, 2000.

Minarno, Nur Basuki. Penyalahgunaan Wewenang Dalam Pengelolaan Keuangan Daerah Yang Berimplikasi Tindak Pidana Korupsi. Surabaya: Laksbang Mediatama, 2010.

Nadir, Sakinah.OtonomiDaerahdanDesentralisasiDesa:Menuju Pemberdayaan Masyarakat Desa, Universitas Hassanudin, Jurnal Politik Profetik, vol. 1 No. 1 Tahun 2013.

Rahardjo, Supratikno. Pengelolaan Warisan Budaya di Indonesia. Bandung: Lubuk Agung, 2011.

Sukasmanto.SeriBukuPintarBUMDesa:RancangBangunBisnis danPengelolaan BUM Desa. Yogyakarta: Forum Pengembangan Pembaharuan Desa (FPPD), 2014.

Tjandra, W. Riawan. Hukum Keuangan Negara. Jakarta: Grasindo, 2013. 
Asep Bambang Hermanto \& Daryan Ciptadi - PENERAPAN GOOD COPORATE GOVERNACE ...

\section{B. PERATURAN PERUNDANGAN-UNDANGAN}

Indonesia. Undang Undang Dasar Negara Republik Indonesia Tahun 1945 Undang-Undang Tentang Keuangan Negara, UU No. 17, LN No. 47 Tahun 2003, TLN. No. 4286.

. Undang-Undang Tentang Desa, UU No. 6, LN No. 7 Tahun 2014, TLN. No. 5495.

. Undang-Undang Tentang Pemerintahan Daerah, UU No. 23, LN No. 244 Tahun 2014.

. Undang-Undang Tentang Administrasi Pemerintahan, UU No. 30, LN No. 292 Tahun 2014, TLN. No. 5601.

- Peraturan Pemerintah Tentang Peraturan Pelaksanaan UndangUndang Nomor 6 Tahun 2014 tentang Desa, PP No. 43, LN No. 123 Tahun 2014, TLN. No. 5539.

- Peraturan Pemerintah Tentang Dana Desa Yang Bersumber dari Anggaran dan Pendapatan Belanja Negara, PP No. 60, LN No. 168 Tahun 2014, TLN. No. 5558. 